\title{
EVOLUTION OF MORPHOMETRIC MEASURES IN THE MANGALARGA MARCHADOR BREED ${ }^{1}$
}

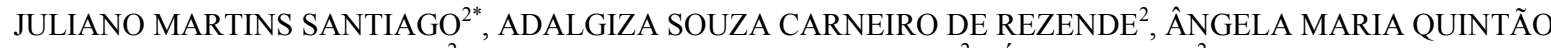 \\ LANA $^{2}$, MAYARA GONÇALVES FONSECA ${ }^{2}$, JÉSSICA LAGE ${ }^{2}$
}

\begin{abstract}
The Mangalarga Marchador breed accounts for the largest horse herd in Brazil and has been experiencing national and international expansion. Nevertheless, there is little scientific production on the evolution of this breed and there are no studies on the morphometric transformations that took place during its formation. In this context, the present study aimed to assess the evolution in morphometric measures of the Mangalarga Marchador breed between 1970 and 2010. The research used information archived at the Brazilian Association of Mangalarga Marchador Breeders from 23,148 males and 92,980 females in a completely randomized experimental design. The six treatments consisted of the animals measured between 1970 and 1979, 1980 and 1989, 1990 and 1994, 1995 and 1999, 2000 and 2004, and 2005 and 2010, respectively. The measures assessed were: height at withers and croup, length of the head, neck, back, croup, shoulder, and body, width of the head and croup, thoracic circumference, and cannon circumference Over the period analyzed, males and females experienced a reduction in thoracic circumference, in the lengths of the head, back, croup, and shoulder, and in the widths of the head and croup. In the males, neck length and cannon circumference also decreased, while body length increased in females. Over time, breed selection led to smaller head, higher stature, and shorter trunk length. However, important measures for the breed's functionality, such as shoulder length and thoracic circumference, decreased.
\end{abstract}

Keywords: Height. Length. Horses. Width. Circumference.

\section{EVOLUÇÃO DAS MEDIDAS MORFOMÉTRICAS DA RAÇA MANGALARGA MARCHADOR}

RESUMO - A raça Mangalarga Marchador é responsável pelo maior rebanho de equinos do país e tem alcançado crescente expansão nacional e internacional. Apesar disso, é escassa a produção científica sobre a evolução dessa raça e não existem estudos sobre as transformações morfométricas que ocorreram ao longo de sua formação. Neste contexto, o presente estudo objetivou avaliar a evolução das medidas morfométricas da raça Mangalarga Marchador entre 1970 e 2010. Foram utilizadas informações arquivadas na Associação Brasileira dos Criadores do Cavalo Mangalarga Marchador de 23148 machos e 92980 fêmeas, em delineamento experimental inteiramente ao acaso. Os seis tratamentos foram constituídos pelos animais mensurados de 1970 a 1979, 1980 a 1989, 1990 a 1994, 1995 a 1999, 2000 a 2004 e 2005 a 2010, respectivamente. As medidas avaliadas foram: alturas na cernelha e garupa, comprimentos da cabeça, pescoço, dorso-lombo, garupa, espádua e corpo, larguras da cabeça e da garupa, além de perímetros torácico e da canela. Ao longo do período avaliado observou-se nos machos e fêmeas redução do perímetro torácico, dos comprimentos da cabeça, dorso-lombo, garupa e espádua e das larguras de cabeça e garupa. Nos machos houve também redução no comprimento do pescoço e aumento no perímetro da canela. Nas fêmeas verificou-se aumento no comprimento do corpo. Ao longo do tempo, a seleção da raça conferiu aos animais menor cabeça, maior estatura e menor comprimento do tronco. No entanto, houve redução de medidas importantes para sua funcionalidade, como o comprimento da espádua e do perímetro torácico.

Palavras-chave: Altura. Comprimento. Equino. Largura. Perímetro.

\footnotetext{
* Corresponding author

${ }^{1}$ Received for publication in $03 / 20 / 2014$; accepted in $11 / 09 / 2015$.

Study extracted from the first author doctorate thesis.

${ }^{2}$ Department of Animal Sciences, Veterinary School of the Federal University of Minas Gerais, Belo Horizonte, MG, Brazil; jmartinssantiago@yahoo.com.br, adalgizavetufmg@gmail.com, angelaquintao@gmail.com, mayaragoncalvesf@hotmail.com, jessicalage@gmail.com.
} 


\section{INTRODUCTION}

Mangalarga Marchador is a Brazilian breed with approximately 200 years of breeding (CASIUCH, 1997) and accounts for the largest and most representative horse herd in the country (LIMA, 2006). According to Cabral et al. (2004), the Mangalarga Marchador breed has amassed admirers all over the country and abroad, reaching significant national and international expansion. According to the ABCCMM (2010), specimens of this breed have been exported to Belgium, Holland, Portugal, Israel, Canada, Uruguay, Peru, United States, and Germany. The largest importers of this breed are the United States and Germany, homes to the U.S. Mangalarga Marchador Association and the European Association of Mangalarga Marchador, respectively.

According to Lima et al. (2006), although the main use of horses in Brazil is in various farming activities, especially in handling bovine cattle, equestrian sports have been increasingly practiced. In order to meet the current demand in the national market, which seeks more athletic horses with higher marching quality whose biotype allures foreign buyers and that best meet the needs of those who use the animals for riding, the Mangalarga Marchador breed has been undergoing adaptations in its breeding aiming to achieve more functional animals.

In 1999, a morphofunctional treaty of the Mangalarga Marchador breed was published (NASCIMENTO, 1999) and, at the time, the author emphasized that, in recent years, Mangalarga Marchador horses tended to evolve into animals with more athletic characteristics, with linear and angular measures required to this role. Also according to that author, the specimens had slenderer and well-sculpted shapes, with the limbs better positioned in relation to the body mass, aiming to improve their performance.

Although the Mangalarga Marchador breed represents one of the largest horse herds worldwide, there is still little scientific production on the different aspects of this breed and no study has been carried out on the morphometric transformations that took place over time. In this context, the present study aimed to assess the evolution of the morphometric measures of the Mangalarga Marchador breed between 1970 and 2010.

\section{MATERIAL AND METHODS}

12 linear measures were analyzed from 23,148 Mangalarga Marchador males and 92,980 females at least three years old and registered in the books MM5 (registry of males of known genealogy) and MM6 (registry of females of known genealogy). The measures were taken from the database of the Genealogic Registry Service of the Brazilian
Association of Mangalarga Marchador Horse Breeders (Associação Brasileira de Criadores do Cavalo Mangalarga Marchador - ADCCMM) between 1970 and 2010 .

The experimental design was completely randomized and the treatments consisted of the animals measured between 1970 and 1979 (81 males and 81 females), 1980 and 1989 (852 males and 934 females), 1990 and 1994 (3,457 males and 21,313 females), 1995 and 1999 (3,176 males and 18,659 females), 2000 and 2004 (4,326 males and 18,654 females), and 2005 and 2010 (11,156 males and 33,339 females) for a total of six treatments.

Height, length, and width were measured using a hipometer while the circumferences were measured with a measuring tape. According to Zamborlini et al. (1996), Lage et al. (2009), and Gonçalves et al. (2012), the measures assessed were measured as follows:

Height at withers - Obtained by placing the ends of the hipometer stick perpendicular to the horizontal plane and the metallic arm horizontally at the highest spot on the withers, between the upper edge of the shoulders;

Height at the croup - Obtained by placing the hipometer stick on the ground perpendicular to the horizontal plane and the metallic arm on the center-most and highest spot of the sacrum region, between the inner angles of the iliac bones;

Thoracic circumference - Measured from the end of the withers to the brisket or the concave part of the sternum;

Cannon circumference - Measured at the medial third of the left metacarpal bone;

Head length - Distance between the proximal end of the head, neck crest, and the medial or central part of the upper incisive dental arch (tip of the snout);

Neck length - Distance between the cranial end of the posterior arch of the atlas and the medial third of the cranial edge of the shoulder;

Back length - Distance between the end of the withers, spinal process of the eighth thoracic vertebrae, and iliac tuberosity;

Croup length - Distance between the external iliac angle or point of hip to the posterior or external ischium angle (point of buttock);

Shoulder length - Distance between the dorsal edge of the shoulder cartilage and the center of the scapulohumeral joint (point of shoulder);

Body length - Distance from the point of shoulder to the point of buttock, measured by placing the metallic arm of the hipometer at the scapulohumeral joint and running the other end of the stick until it touches the point of buttock (posterior or external iliac angle);

Head width - Distance between the right and left temporomandibular joints (region of the right and left sources);

Croup width - Distance between the lateral 
ends of the right and left iliac tuberosities (region of the right and left hips).

The body index was calculated from the ratio between body length and thoracic circumference.

The mean value for each of the 12 measures obtained in each period was related to head length and the result was compared to the proportions recommended for saddle horses by the Eclectic System of Proportions (LESBRE, 1930), which determines that linear measures be related to head length.

In order to adequate the volume of data obtained to the processing capacity of the statistical software, the data underwent random numeric reduction using the software Microsoft Excel version 2010. After the reduction, the results were tested for normal distribution and homoscedasticity among the treatments and underwent analysis of variance and regression using the software SAEG version 9.1.

\section{RESULTS AND DISCUSSION}

A difference $(p<0.05)$ was found over the period assessed for all linear measures in Mangalarga Marchador males (Table 1) and females (Table 2).

The head length in males decreased by $1.4 \mathrm{~cm}$ between 1970 and 2010, from $58.4 \mathrm{~cm}$ in the $1970 \mathrm{~s}$ to $57.0 \mathrm{~cm}$ between 2005 and 2010. The same reduction can be observed when the data in the literature are compared. Carneiro et al. (1952) carried out a preliminary study of the morphometric measures of the Mangalarga Marchador breed and found head length of $59.3 \mathrm{~cm}$. Later, Barbosa (1993) and Zamborlini et al. (1996) described head length of $58.0 \mathrm{~cm}$ and, more recently, in a report published by the ABCCMM in the first attempt to propose an ideal model for the breed (ABCCMM, 2005), head length was $57.0 \mathrm{~cm}$, which is similar to the average over the period assessed in the present study between 2005 and 2010.

In females, the reduction in head length was by $0.8 \mathrm{~cm}$ between 1970 and 2010, with a current average of $56.2 \mathrm{~cm}$. Higher values were found by Barbosa (1993), Zamborlini et al. (1996), ABCCMM (2005), and Gonçalves et al. (2012).

Table 1. Average linear measures of male Mangalarga Marchador horses measured between 1970 and 2010, with their respective degrees of significance (p) and coefficients of variation $(\mathrm{CV})$ and proportions between the linear measures and head length.

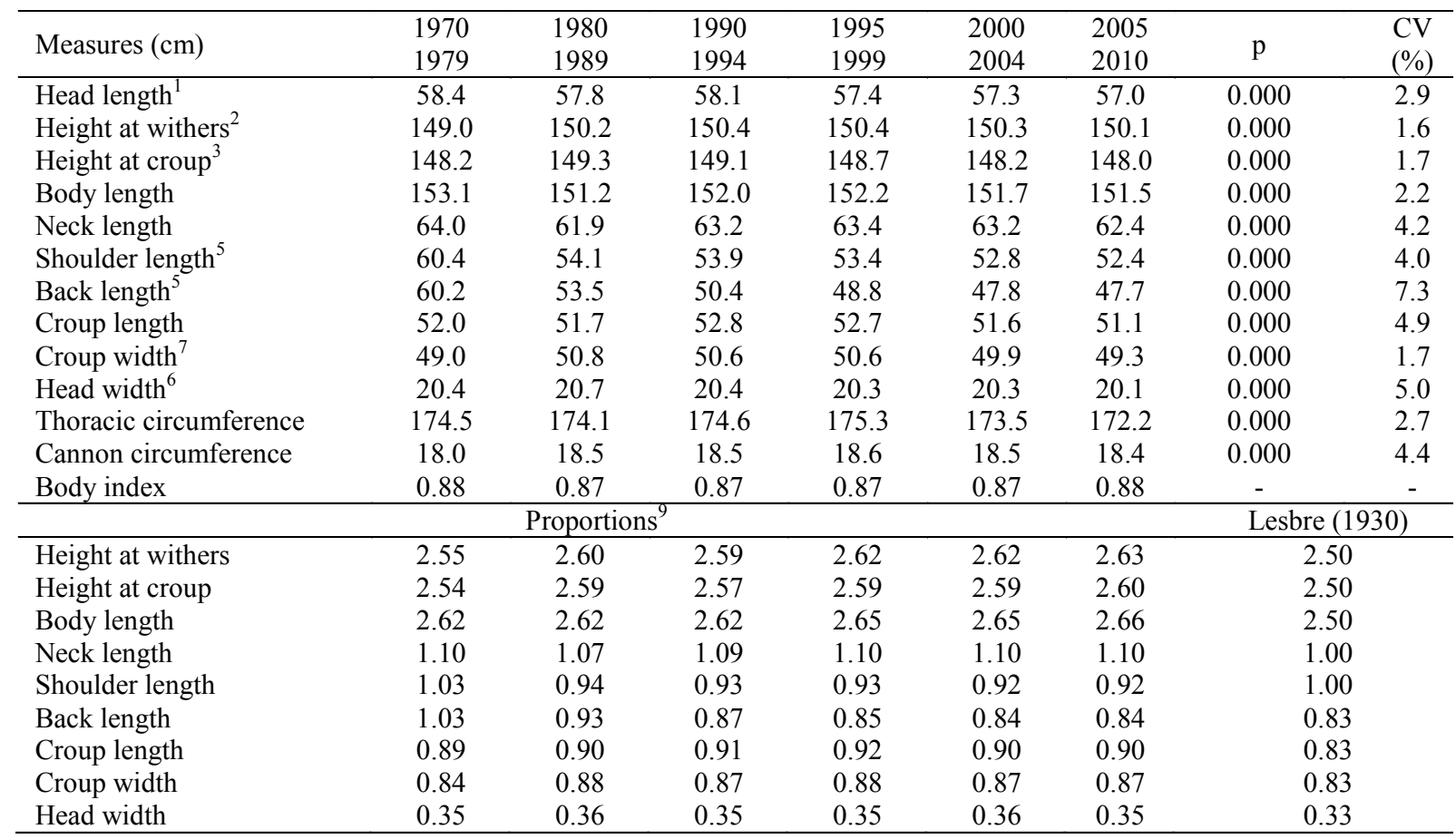

${ }^{1} \mathrm{y}=-0.0004 \mathrm{x}+1.2966\left(\mathrm{r}^{2}=76.13 \%\right) ;{ }^{2} \mathrm{y}=-3 \mathrm{E}-05 \mathrm{x}^{2}+0.1113 \mathrm{x}-109.37\left(\mathrm{r}^{2}=93.06 \%\right) ;{ }^{3} \mathrm{y}=-4 \mathrm{E}-05 \mathrm{x}^{2}+0.1398 \mathrm{x}-137.31$ $\left(\mathrm{r}^{2}=82.26 \%\right) ;{ }^{4} \mathrm{y}=-0.0126 \mathrm{x}^{2}-50.609 \mathrm{x}+50,821\left(\mathrm{r}^{2}=99.21 \%\right) ;{ }^{5} \mathrm{y}=0.0088 \mathrm{x}^{2}-35.115 \mathrm{x}+35,142\left(\mathrm{r}^{2}=84.82 \%\right) ;$ ${ }^{6} \mathrm{y}=-0.0008 \mathrm{x}^{2}+3.3637 \mathrm{x}-3,313.1\left(\mathrm{r}^{2}=68.40 \%\right) ;{ }^{7} \mathrm{y}=-0.0055 \mathrm{x}^{2}+22.016 \mathrm{x}-21,832\left(\mathrm{r}^{2}=92.03 \%\right) ;{ }^{8} \mathrm{y}=-0.0014 \mathrm{x}^{2}+$ $5.6919 \mathrm{x}-5,659\left(\mathrm{r}^{2}=98.66 \%\right)$.

${ }^{9}$ measure assessed/head length measured (LESBRE, 1930). 
Table 2. Average linear measures of female Mangalarga Marchador horses measured between 1970 and 2010, with their respective degrees of significance (p) and coefficients of variation $(\mathrm{CV})$ and proportions between the linear measures and head length.

\begin{tabular}{|c|c|c|c|c|c|c|c|c|}
\hline Measures (cm) & $\begin{array}{l}1970 \\
1979 \\
\end{array}$ & $\begin{array}{l}1980 \\
1989 \\
\end{array}$ & $\begin{array}{l}1990 \\
1994\end{array}$ & $\begin{array}{l}1995 \\
1999\end{array}$ & $\begin{array}{l}2000 \\
2004\end{array}$ & $\begin{array}{l}2005 \\
2010\end{array}$ & $\mathrm{p}$ & $\begin{array}{l}\mathrm{CV} \\
(\%)\end{array}$ \\
\hline Head length $^{1}$ & 57.0 & 56.6 & 56.9 & 56.5 & 56.4 & 56.2 & 0.000 & 3.1 \\
\hline Height at withers $^{2}$ & 144.6 & 145.6 & 145.7 & 146.0 & 146.0 & 145.8 & 0.000 & 2.2 \\
\hline Height at croup ${ }^{3}$ & 144.4 & 145.6 & 145.7 & 145.6 & 145.2 & 144.8 & 0.000 & 2.2 \\
\hline Body length ${ }^{8}$ & 147.6 & 147.7 & 148.6 & 148.8 & 148.5 & 148.7 & 0.000 & 2.7 \\
\hline Neck length $^{4}$ & 59.2 & 59.8 & 60.8 & 61.0 & 61.1 & 60.6 & 0.000 & 4.4 \\
\hline Shoulder length ${ }^{7}$ & 54.7 & 52.7 & 51.4 & 51.2 & 51.1 & 51.0 & 0.000 & 4.3 \\
\hline Back length ${ }^{5}$ & 60.2 & 56.9 & 51.3 & 49.7 & 48.7 & 48.4 & 0.000 & 7.9 \\
\hline Croup length ${ }^{6}$ & 49.6 & 50.8 & 51.1 & 51.1 & 50.5 & 50.3 & 0.000 & 5.0 \\
\hline Croup width $^{10}$ & 48.9 & 50.5 & 50.2 & 50.2 & 49.7 & 49.4 & 0.000 & 2.1 \\
\hline Head width ${ }^{9}$ & 20.4 & 20.4 & 19.9 & 19.7 & 19.9 & 19.8 & 0.000 & 5.4 \\
\hline Thoracic circumference ${ }^{11}$ & 173.8 & 172.4 & 171.2 & 171.6 & 171.2 & 170.8 & 0.000 & 3.4 \\
\hline Cannon circumference ${ }^{12}$ & 17.1 & 17.7 & 17.7 & 17.8 & 17.8 & 17.7 & 0.000 & 3.8 \\
\hline Body index & 0.85 & 0.86 & 0.87 & 0.87 & 0.87 & 0.87 & - & - \\
\hline & \multicolumn{6}{|c|}{ Proporções ${ }^{13}$} & \multicolumn{2}{|c|}{ Lesbre (1930) } \\
\hline Height at withers & 2.54 & 2.58 & 2.56 & 2.59 & 2.59 & 2.60 & \multicolumn{2}{|c|}{2.50} \\
\hline Height at croup & 2.53 & 2.58 & 2.56 & 2.58 & 2.58 & 2.58 & \multicolumn{2}{|c|}{2.50} \\
\hline Body length & 2.59 & 2.61 & 2.61 & 2.64 & 2.64 & 2.65 & \multicolumn{2}{|c|}{2.50} \\
\hline Neck length & 1.04 & 1.06 & 1.07 & 1.08 & 1.08 & 1.08 & \multicolumn{2}{|c|}{1.00} \\
\hline Shoulder length & 0.96 & 0.93 & 0.90 & 0.91 & 0.91 & 0.91 & \multicolumn{2}{|c|}{1.00} \\
\hline Back length & 1.06 & 1.01 & 0.90 & 0.88 & 0.86 & 0.86 & \multicolumn{2}{|c|}{0.83} \\
\hline Croup length & 0.87 & 0.90 & 0.90 & 0.90 & 0.90 & 0.89 & \multicolumn{2}{|c|}{0.83} \\
\hline Croup width & 0.86 & 0.89 & 0.88 & 0.89 & 0.88 & 0.88 & \multicolumn{2}{|c|}{0.83} \\
\hline Head width & 0.36 & 0.36 & 0.35 & 0.35 & 0.35 & 0.35 & \multicolumn{2}{|c|}{0.33} \\
\hline
\end{tabular}

${ }^{1} \mathrm{y}=-2 \mathrm{E}-05 \mathrm{x}^{2}+0.078 \mathrm{x}-76.407\left(\mathrm{r}^{2}=91.24 \%\right) ;{ }^{2} \mathrm{y}=-4 \mathrm{E}-05 \mathrm{x}^{2}+0.164 \mathrm{x}-161.62\left(\mathrm{r}^{2}=94.43 \%\right) ;{ }^{3} \mathrm{y}=-0.0193 \mathrm{x}+95.068\left(\mathrm{r}^{2}\right.$ $=63.52 \%) ;{ }^{4} \mathrm{y}=-0.0024 \mathrm{x}^{2}+9.4616 \mathrm{x}-9,391.9\left(\mathrm{r}^{2}=89.30 \%\right) ;{ }^{5} \mathrm{y}=-0.3654 \mathrm{x}+779.64\left(\mathrm{r}^{2}=94.84 \%\right) ;{ }^{6} \mathrm{y}=0.0038 \mathrm{x}^{2}+$ $15.038 \mathrm{x}-14,908\left(\mathrm{r}^{2}=94.32 \%\right) ;{ }^{7} \mathrm{y}=0.0038 \mathrm{x}^{2}-15.175 \mathrm{x}+15,235\left(\mathrm{r}^{2}=99.62 \%\right) ;{ }^{8} \mathrm{y}=0.0004 \mathrm{x}+0.7409\left(\mathrm{r}^{2}=78.04 \%\right) ;{ }^{9} \mathrm{y}$ $=-0.0209 \mathrm{x}+61.701\left(\mathrm{r}^{2}=76.51 \%\right) ;{ }^{10} \mathrm{y}=-0.0049 \mathrm{x}^{2}+19.451 \mathrm{x}-19,319\left(\mathrm{r}^{2}=87.06 \%\right) ;{ }^{11} \mathrm{y}=-0.0008 \mathrm{x}+3.3196\left(\mathrm{r}^{2}=\right.$ $87.11 \%) ;{ }^{12} \mathrm{y}=-0.001 \mathrm{x}^{2}+3.9075 \mathrm{x}-3,882.2\left(\mathrm{r}^{2}=93.06 \%\right)$.

${ }^{13}$ measure assessed/head length measured (LESBRE, 1930).

According to Gonçalves et al. (2012), horse head length and width are important measures in the morphometric assessment of these animals for providing the breed's expression. According to Fontes (1954) and Nascimento (1999), in the Brazilian marching breeds, the small head, as long as it is balanced, provides, besides aesthetic beauty, functional quality to the animals, particularly if it is associated with a long neck, which facilitates riding and alleviates the thoracic limbs. The head and neck form the cephalocervical equalizer, a sort of counterweight that strongly contributes to the animal's balance and thrust. This is often compared to a "rudder," which is very sensitive and participative when the horse's virtual position and center of gravity movement must be balanced (NASCIMENTO, 1999). Thus, the shorter head length in Mangalarga Marchador horses from 1970 to 2010 may be the result of the animals being used more for riding and, consequently, greater concern by breeders and technicians with functional breeding (conformation versus function). Therefore, breeders and professionals involved with the breed might have valued specimens with shorter heads so as to achieve a better head:neck ratio. Hence, the fore limbs became less loaded, which facilitates walking, cephalocervical equalizer movement, and animal balance.

The mean height at withers in male horses increased from $149.0 \mathrm{~cm}$ in the $1970 \mathrm{~s}$ to $150.2 \mathrm{~cm}$ in the 1980s and remained stable until 2010. Values close to $150.2 \mathrm{~cm}$ were also observed by Barbosa (1993), Zamborlini et al. (1996), Medeiros (2006), and Gonçalves et al. (2012).

The Mangalarga Marchador standard sets the ideal height for males at $152.0 \mathrm{~cm}$, while animals whose height is between $147.0 \mathrm{~cm}$ and $157.0 \mathrm{~cm}$ are accepted for registration. Thus, even with the increase by $1.0 \mathrm{~cm}$ in the males' height at withers between 1970 and 2010, the height considered ideal by the breed's standard has not been reached yet. Greater height at withers was also observed in females, by $1.3 \mathrm{~cm}$ between 1970 and 2010, while the ideal average recommended by the breed's standard for females of $146.0 \mathrm{~cm}$ was reached.

According to the Eclectic System of Proportions for saddle horses (LESBRE, 1930), the ideal proportion between height at withers and head length is 2.5:1 (Tables 1 and 2). A comparison of the proportion between these two measures showed it strayed from the ratio recommended by Lesbre (1930) since it went from $2.55: 1$ in the 1970 s to 
2.63:1 in males in the current herd, and from 2.54:1 to $2: 60: 1$ in females over the same period.

It must be considered that the measures archived at the database of ABCCMM's Genealogic Registry Service might have come from animals still under growth, since the definitive registration is made as early as three years old while horse body development is complete at five years old (FONTES, 1954 and NASCIMENTO, 1999). Given how important the Mangalarga Marchador breed is in Brazil, the new reproductive technologies, and the greater participation of the animals in marcha and morphology contests, breeders could be registering horses at an increasingly younger age and lower physical development level in order to better explore the breed economically. However, Santiago et al. (2013) measured, between 2010 and 2012, height at withers only in male Mangalarga Marchador horses over five years old, i.e., after full physical development, and also found an average of $150.0 \mathrm{~cm}$.

The height at croup in male horses increased between the 1970s and 1980s and gradually decreased between 1980 and 2010. During the last period assessed, between 2005 and 2010, the mean height was $148.0 \mathrm{~cm}$. Similarly to the height at withers, the proportion between the height at croup and head length strayed from the ratio proposed by Lesbre (1930) of $2.5: 1$. In the $1970 \mathrm{~s}$, this proportion in males was $2.54: 1$ and it increased to $2: 60: 1$ between 2005 and 2010 .

When the heights at withers and croup in males in the 1970s are compared, the difference was $0.8 \mathrm{~cm}$, while, between 2005 and 2010, height at withers was $2.1 \mathrm{~cm}$ higher. Croup higher than the withers is considered a disqualifying factor for males (ABCCMM, 2010) since it is associated with inadequate angles of the fore and/or hind limbs, which is harmful to the horse's gait and endurance (CID, 1999). Therefore, the increasing gap between height at withers compared to the croup, found throughout the period assessed, might have resulted from the selection by breeders so the males better fit the breed's standard, which requires horses whose height at withers is the same or higher than the croup.

In females, height at croup decreased by 0.9 $\mathrm{cm}$ between 1980 and 2010, currently at $144.8 \mathrm{~cm}$. Similar values were observed by Zamborlini et al. (1996), while higher values were reported by Medeiros (2006), Pinto (2007), Lage et al. (2009), and Gonçalves et al. (2012). However, Medeiros (2006) used only Mangalarga Marchador females that were champions in morphology, Lage et al. (2009) also assessed only champion animals, and Pinto (2007) measured only females selected by ABCCMM referees. In this case, the better genealogic selection and nutritional management of the animals used in those studies could have resulted in mares with greater body development, which justifies the height at croup above $144.8 \mathrm{~cm}$.

According to the Mangalarga Marchador breed standard, females may receive definitive registration if their height at croup is at most $2 \mathrm{~cm}$ higher than the height at withers (ABCCMM, 2010). Nonetheless, over the years, the height at croup did not become greater than the height at withers, which is currently $1 \mathrm{~cm}$ higher than the height at croup.

The ratio between height at croup and head length in females, as well as in males, strayed from the proportion of 2.5:1 (LESBRE, 1930). However, the greater height at withers and the lower height at croup favored more females fitting the breed's standard.

Male body length varied between 1970 and 2010, from $153.1 \mathrm{~cm}$ in the $1970 \mathrm{~s}$ to $151.5 \mathrm{~cm}$ between 2005 and 2010. Values close to $151.5 \mathrm{~cm}$ were also reported by Barbosa (1993), Zamborlini et al. (1996), Rezende Júnior (2005), Medeiros (2006), and Gonçalves et al. (2012). The proportion between this measure and head length varied less over time since head length also decreased. The shorter body length in males matches the reduction in back and croup lengths found by the present study.

The Eclectic System of Proportions by Lesbre (1930) recommended a ratio between height at withers and body length in saddle horses of $1: 1$. It was found that only in the 1970s was this relation $0.97: 1$, which remained at $0.99: 1$ since then. That shows the Mangalarga Marchador breed evolved with a proportion between height at withers and body length very close to that desirable for the balance of saddle horses.

While in males body length decreased by 1.6 $\mathrm{cm}$, in females this measure increased by $1.1 \mathrm{~cm}$. Since height at withers also increased between 1970 and 2010 , the proportion between body length and height at withers in females remained constant.

Neck length varied in males over the period studied (1970 to 2010). The greatest value was observed in the $1970 \mathrm{~s}(64.0 \mathrm{~cm})$, intermediate values were found between 1990 and 2004, and the lowest measure was observed between 2005 and 2010 $(62.4 \mathrm{~cm})$. Neck lengths close to $62.4 \mathrm{~cm}$ were also reported by Zamborlini et al. (1996), ABCCMM (2005), and Gonçalves et al. (2012).

Neck length was expected to increase in males over the period assessed since a longer neck, provided it is well inserted into the trunk, provides functional quality to the breed (JONES, 1987). The registration of the animals prior to five years old, when physical development finishes in horses, might have contributed to the shorter neck length. In case they were registered at three years old, the males at five years old were likely to have longer necks since, according to Stashak (1994) and Meyer (1995), long bones in horses may develop until three years old, when the epiphyseal disks calcify, but in the short and flat bones, such as cervical vertebrae, epiphyseal plate calcification occurs later, between three and 
five years old. Corroborating this hypothesis, Santiago et al. (2013) reported mean neck length of $63.1 \mathrm{~cm}$ in males over five years old measured between 2010 and 2012, i.e., $0.7 \mathrm{~cm}$ longer than the average found by the present study in males measured between 2005 and 2010 .

However, even with the variation observed in male neck length, the proportion between this measure and head length was similar during most of the period assessed (1.1:1), which is a little higher than the value indicated by Lesbre (1930) of 1:1.

Female neck length increased by $1.9 \mathrm{~cm}$ between 1970 and 2004. Values close to $61.1 \mathrm{~cm}$, observed between 2000 and 2004, were also reported by Barbosa (1993), Zamborlini et al. (1996), and Pinto (2007). This increase was gradual and took place between 1970 and 2004. Between 2005 and 2010 , a reduction by $0.5 \mathrm{~cm}$ was observed. Although neck length decreased, its proportion in relation to head length remained virtually the same since 1995, likely because head length also decreased.

A significant reduction in shoulder length was observed in males, particularly in animals measured in the 1970s. This reduction occurred throughout the period assessed and the lowest value was observed between 2005 and $2010(52.4 \mathrm{~cm})$. In other studies, this measure ranged from 54.0 to $59.0 \mathrm{~cm}$ (BARBOSA, 1993; ZAMBORLINI et al., 1996; LAGE et al., 2009, and GONÇALVES et al., 2012).

In males, the greatest reduction was by $6.3 \mathrm{~cm}$ and took place between the 1970s and 1980s. In females, shoulder length also decreased between 1970 and 2010 and the greatest reduction was also observed between the 1970s and 1980s. According to Rezende and Santiago (2012), the way ABCCMM's genealogic registration technicians measure shoulder length changed in the $1980 \mathrm{~s}$. In the beginning, the shoulder limits were from the scapulohumeral joint to the mid shoulder, including the apophyses of the vertebrae that make up this region. Later, the registration technicians were instructed to change the limits of this measurement, which then corresponded to the length of the scapula bone and excluded the withers.

Both in males and in females, the shorter shoulder length negatively impacted the proportion between head and shoulder length, which became higher than the ratio recommended by the Eclectic System of Proportions for saddle horses (LESBRE, 1930).

Shoulder length and angle are important measures in the quality of movement by horses since they are related to the amplitude of the step and to the dampening of the impact of the limb against the ground, thus directly impacting gait comfort and yield (CAMARGO; CHIEFFI, 1971; CID, 1999 and HARRIS, 1993).

According to Rezende and Santiago (2012), the evolution of the Mangalarga Marchador breed led to horses with better gait quality. In this context, the doubt arises: If the shoulder is so important in marcha quality, why is the reduction in its length not being shown?

One reason for the improvement in marcha quality, even with the shorter shoulder, is in physical compensation. In animal sciences, compensations are qualities, in regions close to a zootechnical defect, that make up for or minimize the effects of these defects in the animal's function (CAMARGO; CHIEFFI, 1971).

Shoulder length must not be assessed by itself. It must be analyzed along with arm length and the angle the shoulder forms with the arms and an imaginary horizontal line. The effects of a short shoulder may be perfectly compensated by a good shoulder and/or arm angle or by a longer arm (REZENDE; SANTIAGO, 2012). It could be inferred that physical compensation for the shorter shoulder took place in the evolution of the Mangalarga Marchador breed, with longer arms and/ or a reduction in the scapula-ground and scapulohumeral angles. That could be verified through a joint analysis between the lengths and angles of the shoulder and arm. However, in ABCCMM's genealogic registration, the technicians did not measure arm length or the scapula-ground and scapulohumeral angles, which makes this impossible to verify.

Between 1970 and 2010, male back length decreased, from $60.2 \mathrm{~cm}$ in the $1970 \mathrm{~s}$ to $47.7 \mathrm{~cm}$ in the current herd. Values above $47.7 \mathrm{~cm}$ were found by Zamborlini et al. (1996), ABCCMM (2005), and Gonçalves et al. (2012).

The literature reports two ways of measuring back length. Both begin after the withers, however, one ends at the iliac tuberosity (BARBOSA, 1993; ZAMBORLINI, et al. 1996; LAGE et al., 2009; and GONÇALVES et al., 2012) while the other goes a little further, until the sacral tuberosity (CLAYTON, 2004). The way ABCCMM's registration technicians measure back length likely changed, which justifies the significant reduction in this measure between the 1970s and 1980s. This suspicion can be strengthened by comparing the coefficients of variation $(\mathrm{CV})$ of the 12 measures assessed since, similarly to Barbosa (1993), back length was the measure that varied the most in males with $\mathrm{CV}$ of 7.3.

The shorter back length over the period assessed brought the ratio between this measure and head length closer to the value proposed by Lesbre (1930). A shorter back is usually stronger, which entails greater efficiency in transmitting the power generated by the hind limbs. Moreover, medium-shaped horses with excessively long backs are weak in this region, which is often associated with hind quarters with little musculature and compromises the animals thrust (JONES, 1987; CID, 1999).

Back length also decreased in females and the proportion between this measure and head length 
became closer to the value recommended by Lesbre (1930). The shortest back length $(48.4 \mathrm{~cm})$ was found between 2005 and 2010 and, similarly to the males, that measure was the one with the greatest variation $(\mathrm{CV}=7.9)$.

Male croup length varied over the period assessed, with a reduction by $0.9 \mathrm{~cm}$ between the $1970 \mathrm{~s}(52.0 \mathrm{~cm})$ and the current herd $(51.1 \mathrm{~cm})$. Only the ABCCMM (2005) report found croup length below $51.1 \mathrm{~cm}$. The other studies reported measures between $52.0 \mathrm{~cm}$ and $55.0 \mathrm{~cm}$ (BARBOSA, 1993; ZAMBORLINI et al., 1996; LAGE et al., 2009; and GONÇALVES et al., 2012). However, the proportion between this measure and head length varied little between 1970 and 2010 .

In horse breeds bred for speed, such as the English Thoroughbred, the longer croup is associated with longer and stronger muscles, which are needed for speed (JONES, 1987). However, in saddle horsed for work, which is the category in which the Mangalarga Marchador breed fits, speed is not the main characteristic explored. Nevertheless, croup length was expected to increase since this breed is subjected to submaximal-intensity exercises (PRATES et al., 2009 and JORDÃO et al., 2011), in which a longer croup provides more power to the hind quarters, a quality that has been highly praised in marcha contests in recent years.

The mean croup length in females was the longest in the 1990s $(51.1 \mathrm{~cm})$, while in the current herd this value is $50.3 \mathrm{~cm}$. Similar values were found by Barbosa (1993) and Zamborlini et al. (1996), while Pinto (2007), Lage et al. (2009), and Gonçalves et al. (2012) reported longer lengths. Despite the variation found in this measure over time, the proportion between croup and head lengths varied little. From 1980 to 2004, this ratio remained constant $(0.90: 1)$ and it slightly decreased in the current herd (0.89:1).

Croup width in males had the highest values between 1980 and 1999 and the lowest in the 1970s and between 2005 and 2010. Similar results were observed in Mangalarga Marchador females. Besides the proportion between croup width and head length, the proportion between croup length and width are also assessed, which must be close or equal to $1: 1$ (LESBRE, 1930). This proportion, over the period assessed, increase compared to the ratio proposed by Lesbre (1930), which indicates a croup that is longer than wide. Throughout the period assessed, the males' croup was longer than wide and the mean ratio between croup length and width was 1.06:1. In males, a narrower croup is accepted. In females, however, this proportion must be carefully assessed since the reduction in croup width may hinder the passage of the foal through the birth canal, which makes the mares more prone to have dystocic deliveries. The results of the present study show that Mangalarga Marchador females maintained a ratio between croup length and width of 1.01:1 during their formation, which is close to the desirable value.

Head width decreased between 1970 and 2010 both in males and females. The proportion between head length and width was similar in the decades assessed, which indicates that the reduction observed in head width was proportional to the reduction in its length.

The thoracic circumference in males decreased over time, from $174.5 \mathrm{~cm}$ in the $1970 \mathrm{~s}$ to $172.2 \mathrm{~cm}$ between 2005 and 2010 . Values above that found in the current herd were reported by all studies investigated (BARBOSA, 1993; ZAMBORLINI et al., 1996; REZENDE JÚNIOR, 2005; MEDEIROS, 2006; LAGE et al., 2009; and GONÇALVES et al., 2012). A similar result was obtained for the thoracic circumference in females.

The Mangalarga Marchador breed has been widely used in several functional activities (long-distance rides, endurance, functional trials, marcha contests, etc.) and, in order for them to develop athletic activities, horses must have good thoracic development (REZENDE et al., 2000). According to Borton (1979), in order for them to reach a satisfactory performance, horses must have a deep rib cage with wide and well-arched ribs. This region, besides providing the basis for the insertion of fore-limb muscles, houses and protects vital organs: heart and lungs.

The reduction in thoracic circumference may be related to the time when the animals were measured for the definitive registration, which is done prior to fiver years old, when the horses have not completed their development yet. However, Nascimento (1999) reported that the current specimens of the breed have more slender shapes. It is therefore possible that the current Mangalarga Marchador herd actually has a smaller thoracic circumference.

The reduction in thoracic circumference may also be related to the nutrition of young horses. Ellis and Lawrence (1978) and Rezende et al. (2000) reported that foals with nutrition deficiency during the first 12 months of life, when the highest growth rate is observed, had a compensatory gain when appropriate nutrition was provided. These animals reached height at withers and body length similar to foals that suffered no nutritional deficiency. However, compensatory gain was not observed in the thoracic circumference measure.

Cannon circumference in males and females increased between 1970 and 2010. This result may indicate that animals with better bone and ligament quality were selected. Besides the genetic factor, appropriate mineral supplementation may have contributed to the increase in metacarpal circumference in Mangalarga Marchador horses.

\section{CONCLUSIONS}


Mangalarga Marchador breeding over the last 40 years led to animals with smaller heads, higher stature, shorter bodies, and greater cannon circumference. However, important measures for the breed's functionality, such as shoulder length and thoracic circumference, decreased.

The morphometric measures of the current Mangalarga Marchador herd are straying from the proportions recommended by the Eclectic System of Proportions by Lesbre for saddle horses.

\section{REFERENCES}

ABCCMM. Associação Brasileira dos Criadores do Cavalo Mangalarga Marchador. Disponível em: <http://www.abccmm.org.br $>$. Acesso em: 30 Jun. 2010.

ASSOCIAÇÃO BRASILEIRA DOS CRIADORES DO CAVALO MANGALARGA MARCHADOR ABCCMM. Primeiro relatório do projeto de avaliação morfométrica em cavalos da raça Mangalarga Marchador ("True Type") da АВССМM. 1. ed. Belo Horizonte, MG: ABCCMM, 2005. $45 \mathrm{p}$

BARBOSA, C. G. Estudo morfométrico na raça Mangalarga Marchador - Uma abordagem multivariada. 1993. 77 f. Dissertação (Mestrado em Zootecnia: Área de Concentração Melhoramento Genético) - Universidade Federal de Minas Gerais, Belo Horizonte, 1993.

BORTON, A. Biología del caballo. In: HINTZ, H. F.; EVANS, J. W. BORTON, A.; VLECK, D. 1. ed. El Caballo. Zaragoza: Acribia, 1979. v. 1, cap. 13, p. 233-334.

CABRAL, G. C. et al. A. Avaliação morfométrica de equinos da raça Mangalarga Marchador: medidas lineares. Revista Brasileira de Zootecnia, Viçosa, v. 33, n. 4, p. 989-1000, 2004.

CAMARGO, M. X.; CHIEFFI, A. Ezoognózia. 1. ed. São Paulo, SP: Instituto de Zootecnia, 1971. 320 p.

CARNEIRO, G. G.; FONTES, L. R.; PEREIRA, H. C. Informações preliminares sobre o cavalo Mangalarga Marchador. Arquivo da Escola Superior de Veterinária, Belo Horizonte, v. 5, n.1, p. 5-22, 1952.

CASIUCH, R. O romance da raça: histórias do cavalo Mangalarga Marchador. 1. ed. São Paulo, SP: Empresa das Artes, 1997. 254 p.

CID, P. S. Hipologia: O Exterior do Cavalo. 1. ed. Lisboa: MG editores, 1999. 103 p.
CLAYTON, H. M. The dynamic horse. 1. ed. Mason: Sport Horse Publications, 2004. 267 p.

ELLIS, N. W., LAWRENCE, T. J. Energy undernutrition in the weanling filly foal.ll. Effects on body conformation and epiphyseal platé closure in the fore limb. British Veterinary Journal, Londres, v. 134, n. 4 , p. 322-332, 1978.

FONTES, L. R. Exterior, raças e julgamento dos animais domésticos. 1. ed. Belo Horizonte, MG: Universidade Rural do Estado de Minas Gerais, 1954. $126 \mathrm{p}$

GONÇALVES, R. W. et al. Efeito da endogamia sobre características morfométricas em cavalos da raça Mangalarga Marchador. Arquivo Brasileiro de Medicina Veterinária e Zootecnia, Belo Horizonte, v. 64, n. 2, p. 419-426, 2012.

HARRIS, S. E. Horse gaits, balance and movement. 1. ed. New York: Howell Book House, 1993. $178 \mathrm{p}$

JONES, W. E. Genética e Criação de Cavalos. 1. ed. São Paulo, SP: Roca, 1987. 666 p.

JORDÃO, L. R. et al. Effect of feed at different times prior to exercise and chelated chromium supplementation on the athletic performance of Mangalarga Marchador mares. Comparative Exercise Physiology, Cambridgeshire, v. 7, n. 3, p. 133-140, 2010

LAGE, M. C. G. R. et al. Associação entre medidas lineares e angulares de equinos da raça Mangalarga Marchador. Arquivo Brasileiro de Medicina Veterinária e Zootecnia, Belo Horizonte, v. 61, n. 4, p. $968-979,2009$.

LESBRE, F. X. Precis d'Exterieur du Cheval. 3. ed. Paris: Vigot Frères, 1930. 608 p.

LIMA R. A. S. Estudo do Complexo do Agronegócio Cavalo no Brasil. 1. ed. Brasília, DF: CNA/MAPA, 2006. 66 p.

MEDEIROS, L. S. Medidas morfométricas dos garanhões campeões e não campeões da raça Mangalarga Marchador. 2006. 20 f. Monografia (Conclusão do curso de Zootecnia) - Universidade José do Rosário Vellano, Alfenas, 2006.

MEYER, H. Alimentação de cavalos. 1. ed. São Paulo, SP: Varela, 1995. 303 p.

NASCIMENTO, J. F. Mangalarga marchador: tratado morfofuncional. 1. ed. Belo Horizonte, MG: ABCCMM, 1999. 577 p. 
PINTO, B. P. Avaliação morfométrica de éguas da raça Mangalarga Marchador. 2007. 42 f. Monografia (Conclusão do curso de Medicina Veterinária) - Pontifícia Universidade Católica de Minas Gerais, Betim, 2007.

PRATES, R. C. et al. Heart rate of Mangalarga Marchador mares under march test and supplemented with chrome. Revista Brasileira de Zootecnia, Viçosa, v. 38, n. 5, p. 916-922, 2009.

REZENDE JÚNIOR, S. F. Avaliação de características morfométricas de garanhões da raça Mangalarga Marchador registrados entre os anos de 1984 e 2004. 2005. 17 f. Monografia (Conclusão do curso de Zootecnia) - Universidade José do Rosário Vellano, Alfenas, 2005.

REZENDE, A. S. C. et al. Efeito de dois diferentes programas nutricionais sobre o desenvolvimento corporal de potros Mangalarga Marchador. Revista Brasileira de Zootecnia, Viçosa, v. 29, n. 2, p. 495501, 2000.

REZENDE, A. S. C., SANTIAGO, J. M. True Type, modelo ideal da raça. Revista Oficial da АВССМM, Belo Horizonte, v, 75, n. 1, p. 86-93, 2012.

SANTIAGO, J. M. et al. Comparação entre as medidas morfométricas do rebanho atual de machos Mangalarga Marchador e dos campeões da raça. Boletim da Indústria Animal, Nova Odessa, v. 70, n. 1, p. 46-52, 2013.

STASHAK, O. R. Claudicação em equinos segundo Adams. 4. ed. São Paulo, SP: Roca, 1994. $943 \mathrm{p}$.

ZAMBORLINI, L. C. et al. Estudo genéticoquantitativo de medidas lineares de equinos da raça mangalarga marchador - I. Estimativas dos fatores de ambiente e parâmetros genéticos. Revista Brasileira de Ciências Veterinárias, Niterói, v. 3, n. 2, p. 3337, 1996. 